\author{
Olexandr Pivovarov, Roman Zakharov and Mykola Nikolenko
}

\title{
TREATMENT OF AQUEOUS SOLUTIONS OF SODIUM CHLORIDE BY NONEQUILIBRIUM LOW TEMPERATURE PLASMA
}

\author{
Ukrainian State University of the Chemical Engineering \\ 8, Gagarin Ave., 49005 Dnipropetrovsk, Ukraine \\ r_zakharov88@mail.ru
}

Received: M arch 05, 2013 / Revised: April 05, 2013 / Accepted: October 22, 2013

(C) Pivovarov O., Zakharov R., Nikolenko M., 2015

\begin{abstract}
The kinetics of chemical transformations in water solutions of sodium chloride under conditions of plasma processing in gas-liquid periodic plasma-chemical reactor of blending was studied. The mathematical model including stages of oxidation of water molecules and chlorides-ions as well as stages of decomposing of metasable products of chemical transformations was offered.
\end{abstract}

Keywords: water solutions, mathematical model, plasmachemical reactor, sodium chloride, kinetics of chemical transformations.

\section{Introduction}

In view of growing requirement for water resources, scientific research in the field of water purification and preparation for use becomes of special importance. Much attention is paid to studying methods of treating aqueous solutions using contact nonequilibrium low temperature plasma (CNP) $[1,2]$. Plasma discharge is generated between the electrode placed in gaseous phase and the surface of liquid in space of which the second electrode is situated. During such a discharge a great number of various chemically active particles (free and hydrated electrons, protons, radicals, charged and exited ions, atoms and molecules) are being generated. Investigation of chemical transformations in such media appears to be a difficult problem.

Some authors [3] proposed a kinetic model of chemical transformations in distilled water subjected to plasma. The model includes 41 reactions with the participation of 15 reaction components: $e_{\text {solv }}, \mathrm{OH}, \mathrm{O}^{-}$, $\mathrm{O}_{2}^{-}, \mathrm{HO}_{2}^{-} \mathrm{O}_{3}^{-}, \mathrm{OH}^{-}, \mathrm{H}^{+}, \mathrm{H}_{2}, \mathrm{O}_{2}, \mathrm{H}_{2} \mathrm{O}_{2}, \mathrm{HO}_{2}, \mathrm{H}_{2} \mathrm{O}_{3}$, and $\mathrm{H}_{2} \mathrm{O}$. It is shown that the calculations performed agree with experimental data on accumulation of peroxide compounds in the solutions only at the initial stage of their plasma treatment. Nonequilibrium of plasma discharge and diversity of radical particles interaction processes complicate significantly the kinetic model of the process and do not allow to determine the character of influence of such parameters as strength of current, current density, pressure in the reactor, acidity of the solutions, and their ionic composition.

The chemical transformations of water under the action of plasma have been studied for a long time while the question of plasma discharge influence on aqueous solutions of sodium chloride remains insufficiently studied so far. Scientific and practical interest of studying the process of plasma chemical treatment of $\mathrm{NaCl}$ solutions depends on chlorine properties. Its compounds with oxygen are known to be notable for relatively high oxidability and have already found wide application in various industrial technologies. In previous work [4] we drew up a probable diagram of $\mathrm{H}_{2} \mathrm{O}$ and $\mathrm{NaCl}$ chemical transformations based on thermodynamic diagrams of Purbie for chlorine and oxygen. It was found that acidity of $\mathrm{NaCl}$ solutions changes under the influence of $\mathrm{CNP}$, and hydrogen peroxide and hypochlorite ions are generated and quickly react with $\mathrm{H}_{2} \mathrm{O}_{2}$ forming chlorite ions.

In the present work, we attempt to investigate chemical transformations of sodium chloride solutions in plasma reactor on the basis of modeling probable redox processes with the participation of relatively stable nonradical particles. Based on the data on kinetic parameters of stages of $\mathrm{NaCl}$ aqueous solutions plasmochemical decomposition mathematical model of oxidizing agents synthesis was developed. For the first time the curves of basic components distribution in reaction medium depending on time of solutions plasma-chemical treatment and pressure in the reactor have been obtained. The results of conducted calculations were proved by experimental studies of solutions chemical composition. 


\section{Experimental}

The studies were carried out in a model gasliquid plasma reactor of batch operation. Barrel-type reactor with inside diameter of $45 \mathrm{~mm}$ and $85 \mathrm{~mm}$ in height was used. Cooling of reaction mixture was provided by continuous circulation of cold water in outer jacket. Electrodes were made of stainless steel; one of the electrodes (diameter $4 \mathrm{~mm}$ ) was placed in the lower part of the reactor and the other one (diameter $2.4 \mathrm{~mm}$ ) was placed at a distance of $10 \mathrm{~mm}$ above the solution surface. To get plasma discharge voltage of 500-1000 V was applied to electrodes. Pressure in the reactor was held constant by vacuum pump. The time of plasma treatment of sodium chloride solutions varied within the range from 2 to $20 \mathrm{~min}$. The volume of the solution in the reactor was $50 \mathrm{ml}$.

The solutions of sodium chloride were prepared by dissolving $\mathrm{NaCl}$ samples of P.A. purity in flasks with distilled water. To avoid possible losses of volatile products of oxidation in a number of cases initial solutions of $\mathrm{NaCl}$ were previously alkalified up to $\mathrm{pH} \sim 11$ by adding sodium hydroxide. Total content of oxidizers in the solutions treated by plasma were determined by iodometric titration method [5]: hydrogen peroxide content was determined in the medium of acetate buffer solution, in $1 \mathrm{M}$ solutions of sulfuric acid total content of $\mathrm{H}_{2} \mathrm{O}_{2}$ and $\mathrm{ClO}_{2}^{-}$was determined and in $4 \mathrm{M}$ solutions of $\mathrm{HCl}$ the sum of $\mathrm{H}_{2} \mathrm{O}_{2}, \mathrm{ClO}_{2}{ }^{-}$and $\mathrm{ClO}_{3}{ }^{-}$was titrated. The content of perchlorate ions was determined photometrically at wave length $520 \mathrm{~nm}$ using methylene blue, which forms ionic associates of violet coloration with $\mathrm{ClO}_{4}^{-}$[6]. In order to remove oxidants the samples of the solutions under investigation were previously boiled out practically to dryness in the presence of sulfuric acid.

\section{Results and Discussion}

During preliminary experiments with $\mathrm{NaCl}$ solutions with concentrations $1-3 \mathrm{~g} / \mathrm{l}$ it was found that at plasma treatment of solutions hydrogen peroxide and chlorite ions are accumulated in liquid phase. With the rise of $\mathrm{CNP}$ exposure time $\mathrm{H}_{2} \mathrm{O}_{2}$ concentration was constantly increasing and $\mathrm{ClO}_{2}^{-}$content was first increasing, then it stopped changing and even began decreasing. Examination of possible variants of kinetic models shows that it is possible to explain the above regularities only when taking into account the processes of chlorite ions decomposition due to their oxidation or reduction. Therefore, the studies employing more detailed analysis of the $\mathrm{NaCl}$ solutions subjected to plasma action were carried out.
An example of the data obtained is given in Figs. 1 and 2. It was found that during CNP action together with the formation of hydrogen peroxide and chlorites chlorates and perchlorates are formed. The content of the latter is constantly increasing while $C(t)$ relationship for chlorites and chlorates has a form of saturation curves. Absence of hypochlorite ions in the solutions is well explained by their fast interaction with hydrogen peroxide [4]:

$$
\begin{gathered}
\mathrm{H}_{2} \mathrm{O}_{2}+\mathrm{ClO}^{-} \rightarrow \mathrm{ClO}_{2}^{-}+\mathrm{H}_{2} \mathrm{O} \\
\mathrm{H}_{2} \mathrm{O}_{2}+\mathrm{ClO}^{-} \rightarrow \mathrm{Cl}^{-}+\mathrm{O}_{2}+\mathrm{H}_{2} \mathrm{O}
\end{gathered}
$$

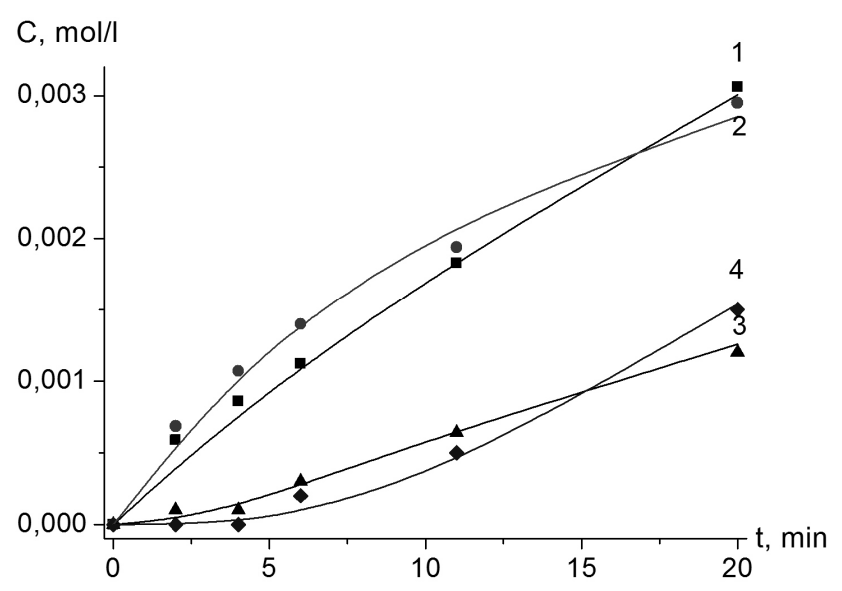

Fig. 1. Dependences between $\mathrm{H}_{2} \mathrm{O}_{2}(1), \mathrm{ClO}_{2}^{-}(2), \mathrm{ClO}_{3}^{-}$(3) and $\mathrm{ClO}_{4}^{-}$(4) concentrations in $\mathrm{NaCl}$ solutions (cons. $3.0 \mathrm{~g} / \mathrm{l} ; \mathrm{pH}$

11.7) and the time of CNP treatment at current $140 \mathrm{~mA}$ and pressure in the reactor $19.6 \mathrm{kPa}$. (The dots show the experimental data, and the curves are constructed as based on the mathematical model)

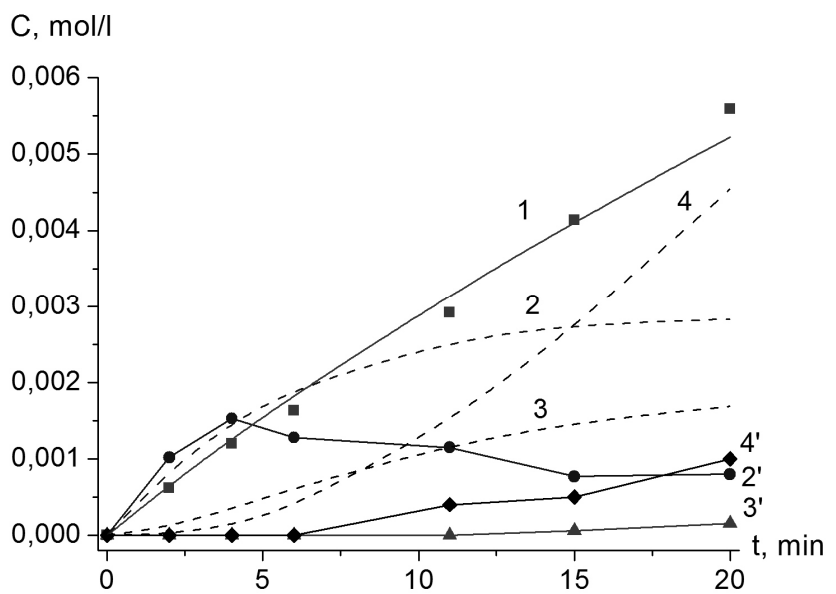

Fig. 2. Dependences between $\mathrm{H}_{2} \mathrm{O}_{2}(1), \mathrm{ClO}_{2}^{-}\left(2,2^{\prime}\right), \mathrm{ClO}_{3}^{-}$ $(3,3)$ and $\mathrm{ClO}_{4}^{-}\left(4,4^{\prime}\right)$ concentrations in $\mathrm{NaCl}$ solutions (cons. $3.0 \mathrm{~g} / \mathrm{l} ; \mathrm{pH} 7.4$ ) and the time of CNP treatment at current $140 \mathrm{~mA}$ and pressure in the reactor $19.6 \mathrm{kPa}$. (Line 2', 3' and 4 'are based on the experimental data) 
When working out a kinetic model of the process investigated it was taken into account that in aqueous solutions of sodium chloride possible chemical interactions are defined both by oxidation reactions of water molecules (also OH-ions), chlorine ions, intermediate product of oxidation and reduction reactions of the same water molecules (and $\mathrm{H}^{+}$ions), as well as oxidation products of chlorine ions. The diagram of possible transformations is given in Fig. 3 and in Table.

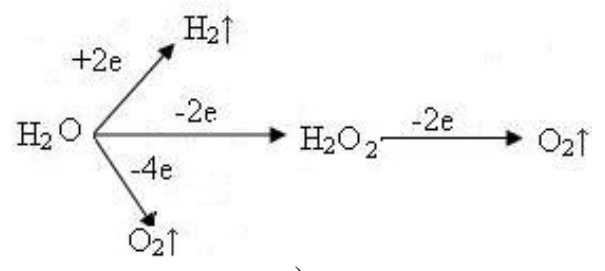

a)

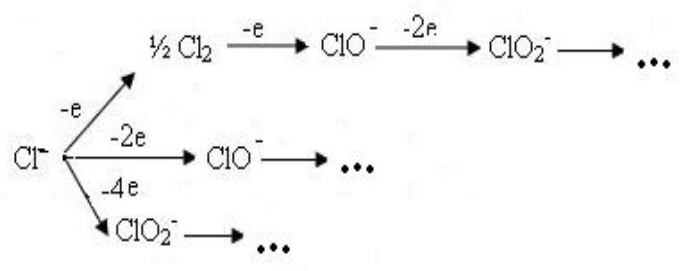

b)

Fig.3. The scheme of possible transformations of water molecules and chloride ions in the solutions subjected to plasma treatment

In order to simplify the kinetic model as much as possible the diagram of water molecules and chlorine ions was set up without specifying particular forms of reagent serving as an oxidizer: these can be particles $\mathrm{H}_{2} \mathrm{O}^{+}, \mathrm{OH} \cdot$ or any other forms of particles with unpaired number of electrons. We adopted that in stationary state the concentration in the solution is held constant and therefore it can be included in the reaction rate constant at the given stage of the process.

In the transformation diagram suggested we did not take into account the possibility of $\mathrm{Cl}_{2}$ particles formation, especially in alkali solutions chlorine disproportionates rather quickly:

$$
\begin{aligned}
& \mathrm{Cl}_{2}+\mathrm{H}_{2} \mathrm{O} \rightarrow \mathrm{HClO}+\mathrm{Cl}^{-}+\mathrm{H}^{+} \\
& \mathrm{Cl}_{2}+2 \mathrm{OH}^{-} \rightarrow \mathrm{ClO}^{-}+\mathrm{Cl}^{-}+\mathrm{H}_{2} \mathrm{O}
\end{aligned}
$$

Thus, in view of the above assumptions and according to mass action law mathematical model of the process occurring in plasma reactor can be represented as a system of differential equations:

$$
\begin{gathered}
\frac{d}{d t} C_{A}=-k_{1} C_{A} \\
\frac{d}{d t} C_{B}=k_{1} C_{A}-k_{2} C_{B}-k_{4} C_{B} C_{E}
\end{gathered}
$$

$$
\begin{gathered}
\frac{d}{d t} C_{C}=k_{2} C_{B} \\
\frac{d}{d t} C_{D}=k_{6} C_{E}-k_{3} C_{D} \\
\frac{d}{d t} C_{E}=k_{3} C_{D}+k_{8} C_{F}-k_{6} C_{E}-k_{5} C_{E}-k_{4} C_{B} C_{E} \\
\frac{d}{d t} C_{F}=k_{5} C_{E}+k_{10} C_{G}-k_{8} C_{F}-k_{7} C_{F}+k_{4} C_{B} C_{E} \\
\frac{d}{d t} C_{G}=k_{7} C_{F}-k_{9} C_{G}-k_{10} C_{G}+k_{11} C_{H} \\
\frac{d}{d t} C_{H}=k_{9} C_{G}-k_{11} C_{H}
\end{gathered}
$$

where $A-\mathrm{H}_{2} \mathrm{O}, B-\mathrm{H}_{2} \mathrm{O}_{2}, C-\mathrm{O}_{2}, D-\mathrm{Cl}^{-}, E-\mathrm{ClO}^{-}, F-$ $\mathrm{ClO}_{2}^{-}, G-\mathrm{ClO}_{3}^{-}, H-\mathrm{ClO}_{4}^{-}$.

As boundary conditions the following initial concentrations of reagents were used: $C_{A}=55.6 \mathrm{~mol} / \mathrm{l}$, $C_{D}=0.05 \mathrm{~mol} / \mathrm{l}$ (solution $\mathrm{NaCl}$ with concentration $3 \mathrm{~g} / \mathrm{l}$ ), $C_{B}=C_{C}=C_{E}=C_{F}=C_{H}=0$.

To calculate possible reaction rate constants for redox reactions in approximation to the above considered mathematical model of plasma process model of batch stirred reactor was employed. The losses of the substance during vacuum treatment were neglected as the examinations were being conducted for no more than $20 \mathrm{~min}$. Stirring of the solution in the reactor was conditioned by the gas bubbles evolution both on the cathode surface and in the bulk of solution. Mass transfer between the liquid in plasma tongue zone and the rest of its volume were not taken into account for the reason of relatively small sizes of the reactor and small bulk of the solution $(50 \mathrm{ml})$.

Differential equations system (5)-(12) was solved by Runge-Kutt method with fixed integration step. Based on experimental data and mathematical model reaction rate constants of all stages of chemical transformations were calculated, the latter being presented in the Table.

The best agreement of calculated and experimental data was received for the studies with alkali solution of sodium chloride (Fig. 1). We failed to fit values of rate constants at which $C(t)$ dependences would fully coincide with experimental data. Calculations for chlorites (Fig. 2, curve 2) agree with experimental data only on the initial section of kinetic dependences, while for chlorates and perchlorates they show that their content in the solutions must be by an order of magnitude greater than it was established experimentally. Detailed analysis of data shown in Fig. 2 proves that the important factor in such an "abnormal" discrepancy between the model and 
the experiment is rapid reduction of $\mathrm{pH}^{1}$ of the solutions tested: in $5 \mathrm{~min} \mathrm{pH}$ decreases by 4 units and continues decreasing in accordance with the discharge action on the solution (Fig. 4, curve 2).

The stages of chemical reactions and the observed rate constants $(C(\mathrm{NaCl})=3 \mathrm{~g} / \mathrm{l}, I=140 \mathrm{~mA}, p=19.6 \mathrm{kPa})$

\begin{tabular}{|l|c|c|}
\hline \multirow{2}{*}{ Stages of chemical reactions } & \multicolumn{2}{|c|}{$k, \mathrm{~min}^{-1}$} \\
\cline { 2 - 3 } & $\begin{array}{c}\mathrm{pH}= \\
=.5-11.7\end{array}$ & $\begin{array}{c}\mathrm{pH}= \\
=2.8-7.4\end{array}$ \\
\hline $\mathrm{H}_{2} \mathrm{O} \stackrel{k 1}{\longrightarrow} \mathrm{H}_{2} \mathrm{O}_{2}$ & $0.9 \cdot 10^{-5}$ & $1.5 \cdot 10^{-5}$ \\
\hline $\mathrm{H}_{2} \mathrm{O}_{2} \stackrel{k 2}{\longrightarrow} \mathrm{O}_{2}$ & 0.03 & 0.035 \\
\hline $\mathrm{Cl}^{-} \stackrel{k 3}{\longrightarrow} \mathrm{ClO}^{-}$ & 0.006 & 0.01 \\
\hline $\mathrm{ClO}^{-}+\mathrm{H}_{2} \mathrm{O}_{2} \underset{k 4}{\longrightarrow} \mathrm{ClO}_{2}^{-}$ & $1 \cdot 10^{5}$ & $1 \cdot 10^{5}$ \\
\hline $\mathrm{ClO}^{-} \stackrel{k 5}{\longrightarrow} \mathrm{ClO}_{2}^{-}$ & 0.044 & 0.08 \\
\hline $\mathrm{ClO}^{-} \stackrel{k 6}{\longrightarrow} \mathrm{Cl}^{-}$ & 0.01 & 0.01 \\
\hline $\mathrm{ClO}_{2}^{-} \stackrel{k 7}{\longrightarrow} \mathrm{ClO}_{3}^{-}$ & 0.08 & 0.15 \\
\hline $\mathrm{ClO}_{2}^{-} \stackrel{k 8}{\longrightarrow} \mathrm{ClO}^{-}$ & 0.01 & 0.01 \\
\hline $\mathrm{ClO}_{3}^{-} \stackrel{k 9}{\longrightarrow} \mathrm{ClO}_{4}^{-}$ & 0.14 & 0.25 \\
\hline $\mathrm{ClO}_{3}^{-} \stackrel{k 10}{\longrightarrow} \mathrm{ClO}_{2}^{-}$ & 0.01 & 0.01 \\
\hline $\mathrm{ClO}_{4}^{-} \stackrel{k 11}{\longrightarrow} \mathrm{ClO}_{3}^{-}$ & 0.01 & 0.01 \\
\hline
\end{tabular}

$\mathrm{pH}$

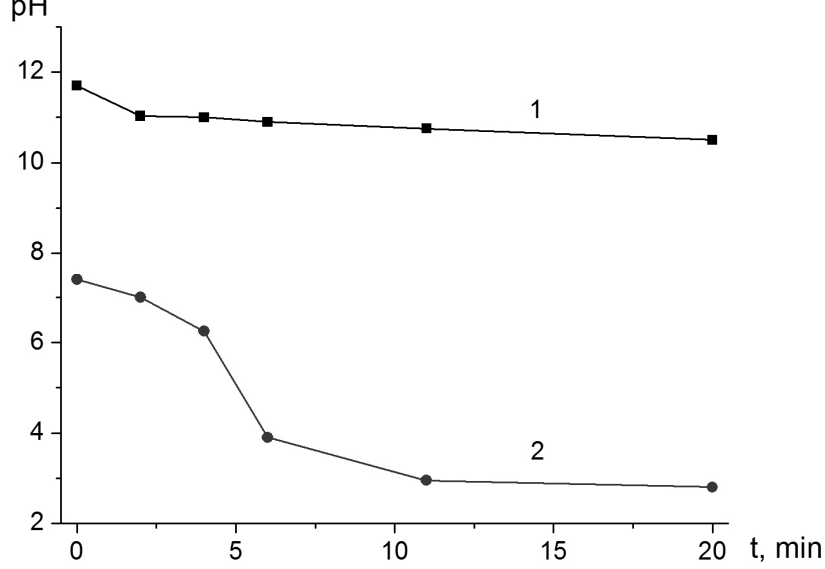

Fig. 4. Changing of acidity of alkaline (1) and neutral (2) solutions of sodium chloride in the process of their plasma treatment $(C(\mathrm{NaCl})=3 \mathrm{~g} / \mathrm{l}, I=140 \mathrm{~mA}, p=19.6 \mathrm{kPa})$

${ }^{1}$ Changes in acidity of the aqueous solutions in the process of plasma treatment thereof is explained by combined effect of the cathodic process of hydrogen release $\left(2 \mathrm{H}_{2} \mathrm{O}+2 \mathrm{e} \rightarrow\right.$ $\left.\rightarrow \mathrm{H}_{2}+2 \mathrm{OH}^{-}\right)$and the anodic process of water oxidation $\left(2 \mathrm{H}_{2} \mathrm{O}-4 \mathrm{e} \rightarrow \mathrm{O}_{2}+4 \mathrm{H}^{+}\right)$. Besides, it is necessary to take into account the possibility of $\mathrm{H}^{+}$and $\mathrm{OH}^{-}$ions participation in the processes of chlorine ions oxidation and in the potential interactions of the reaction products with hydrogen peroxide [4].

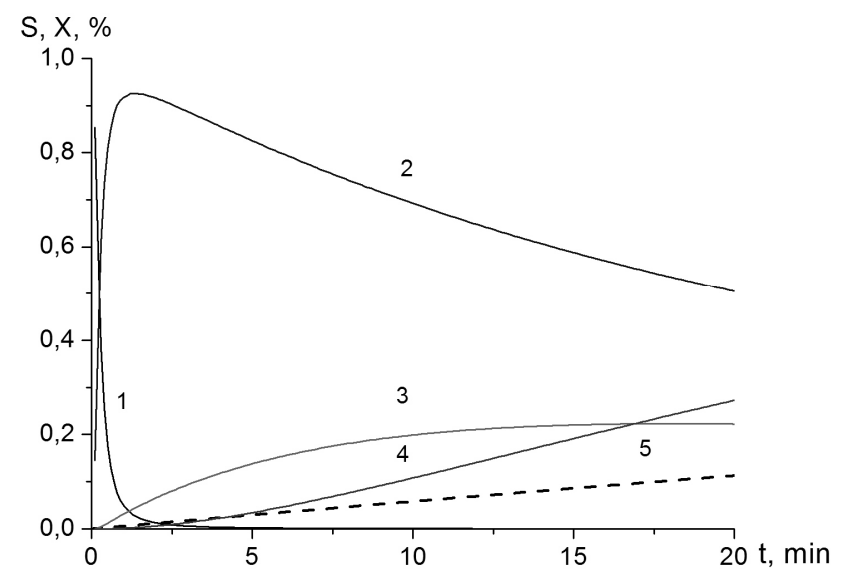

Fig. 5. Selectivity of formation of $\mathrm{ClO}^{-}(1), \mathrm{ClO}_{2}^{-}(2), \mathrm{ClO}_{3}^{-}(3)$, $\mathrm{ClO}_{4}^{-}$(4) ions and degree of transformation of sodium chloride (5) in the solution with initial $\mathrm{pH}$ of 11.7

In acidic solutions ion forms of chlorine $(+1,+3)$ oxygen compounds are known to pass into molecular ones ( $\mathrm{HClO}$ and $\mathrm{HClO}_{2}$ ), which makes them more labile for evaporation. It should also be noted that in acidic solutions $\mathrm{HClO}$ and $\mathrm{HClO}_{2}$ are relatively rapidly transformed with the generation of volatile substances:

$$
\begin{gathered}
\mathrm{HClO}+\mathrm{H}^{+}+\mathrm{Cl}^{-} \rightarrow \mathrm{Cl}_{2} \uparrow+\mathrm{H}_{2} \mathrm{O} \\
2 \mathrm{HClO} \rightarrow \mathrm{O}_{2} \uparrow+2 \mathrm{H}^{+}+2 \mathrm{Cl}^{-} \\
\mathrm{HClO}_{2} \rightarrow \mathrm{O}_{2} \uparrow+\mathrm{H}^{+}+\mathrm{Cl}^{-}
\end{gathered}
$$

Therefore, the discrepancy observed between experimental and calculated data for the acidic solutions can be explained by additional losses of oxygen compounds of chlorine due to their disproportionation and evaporation.

Thus, calculation data on kinetic model developed are in good agreement with the well-known concepts about chemistry of chlorine and hydrogen peroxide. It will be interesting to investigate temperature dependences of rate constants in order to obtain full data on kinetic parameters of basic stages of plasma process and to confirm experimentally the possibility to carry out the process involved in a mixed diffusion-kinetic regime. It should be noted that the task of optimizing the process of plasma treatment of saline solutions is rather complicated one, since it is necessary to take into account the wide range of optimizing parameters. As an example, Fig. 5 shows the results of calculations of the degree of transformation of sodium chloride and selectivity of formation of chlorine-containing ions.

In the model reactor conditions, degree of sodium chloride transformation even after $20 \mathrm{~min}$ of plasma treatment reaches $10 \%$ only, and selectivity of generation of the target product - sodium chlorite (Fig. 5, curve 2) is decreasing rapidly. Similar change is observed in selectivity of the process on hypochlorite-ions (Fig. 5, 
curve 1), which is connected with their quick consumption in chemical reactions (1) and (2). It was also found that with the increase in time of CNP action on the sodium chloride solutions selectivity of the process on $\mathrm{ClO}_{3}{ }^{-}$ increased at first, but in 10 min of plasma action it stopped changing and remained at the level of $25 \%$, with the selectivity for $\mathrm{ClO}_{4}^{-}$constantly growing. Within the framework of chemical model of the process considered above, these patterns can be explained by the fact that under discharge action there occurs continuous oxidation of chloride ions to hypochlorites, chlorites, chlorates, and perchlorates. Therefore, long-term plasma treatment of sodium chloride solutions using CNP is not feasible because of rapid decrease in selectivity of the process for the most valuable, in terms of oxidizing capacity, products.

\section{Conclusions}

The investigations of chemical transformations in aqueous solutions of sodium chloride under the action of CNP glow discharge have shown that all the regularities of changes in solutions compositions can be explained in approximation to kinetic model including stages of oxidizing water molecules, chloride ions, and chlorine oxygen compounds as well as stages of decomposing (reducing) metastable products of chemical transformations.

For the first time the curves of content distribution of basic components in reaction medium depending on time of solutions plasma treatment and sodium chloride concentration were calculated. It was shown that long plasma treatment of sodium chloride solutions appears to be inexpedient because a "ballast" (as to oxidizing pro- perties) substance is being accumulated in the solutions. This substance is sodium perchlorate.

The data obtained allows making purposeful choice of conditions for plasma treatment of sodium chloride solutions in order to obtain solutions with predicted content of hydrogen peroxide, hypochlorites, chlorites and chlorates. These solutions can be used when bleaching and preparing fabrics for dyeing, when disinfecting various surfaces at food industry enterprises, and so on.

\section{References}

[1] Zakharov A., Maksimov A. and Titova Y.: Yspekhi Khimii, 2007, 76, 260.

[2] Pivovarov A. and Tishenko A.: Neravnovesnaya Plazma: Processy Aktivacii Vody i Vodnykh Rastvorov. Grek, Dnipropetrovsk 2006.

[3] Pivovarov A. and Sergeeva O.: Voprosy Khimii i Khim. Techn., 2001, 5, 74.

[4] Pivovarov A., Nikolenko N., Zakharov R. et al.: Voprosy Khimii i Khim. Techn., 2012, 3, 127.

[5] Yil'ams Y.: Opredelenie Anionov. Khimia, Moskwa 1982.

\section{ОБРОБЛЕННЯ ВОДНИХ РОЗЧИНІВ ХЛОРИДУ НАТРІЮ КОНТАКТНОЮ НЕРІВНОВАЖНОЮ НИЗЬКОТЕМПЕРАТУРНОЮ ПЛАЗМОЮ}

Анотація. Вивчено закономірності хімічних перетворень у водних розчинах хлориду натрію за умов плазмового оброблення в газорідинному плазмохімічному реакторі змішування періодичної діï. Запропоновано математичну модель, яка включає стадії окиснення молекул води і хлорид-йонів, а також стадї розкладання метастабільних продуктів хімічних перетворень.

Ключові слова: водні розчини, математична модель, плазмохімічний реактор, хлорид натрію, кінетика хімічних реакиій. 
